\title{
Evolution in a Contemporary Japanese Community
}

\author{
Harumi BEFU
}

LASKER (1960) has collected date on size of the breeding population and rates of admixture for a number of communities in Latin America and elsewhere and has urged collection of similar data from other parts of the world. Analysis to. follow presents comparable data from a hamlet in northern Japan in the outskirts of Sendai, the capital of Miyagi Prefecture. Raw data were collected in, and therefore is valid for, May, 1959. Though located within the administrative limits of the city of Sendai, Shimo-okada, our datum community, is on the whole a rice growing agricultural community, and it may be considered as representative of a great number of rural communities of Japan. ${ }^{1)}$

Since there is a general consensus among Japanese and American anthropologists specializing on Japan that a hamlet (commonly called buraku) in Japan, such as Shimo-okada, is a rather self-contained unit, it would be interesting to. see how much this assumption is sustained by physical anthropological date. Of course, data of this sort, such as the rate of admixture, is not immediately to. be taken as indicative of cultural phenomena. But certain aspects of cultural phenomena do have close relation to biological and demographic factors. The degree of ingrownness, cultural and social isolation of a community, etc., are just such phenomena. The data to be presented, then, should be of interest to. both physical and cultural anthropologists.

First, proportion of immigrants in the Shimo-okada population well be given. Size of the breeding population will then be calculated, followed by the rate of admixture, size of the effective breeding population and the rate of random gene drift.

\section{Percentage of immigrants}

The total population of Shimo-okada is 490, of whom 238 are males and 252 females. Of the 490, 342 are natives, i. e., born in Shimo-okada and 131 immigrants, i. e., born outside the community. Seventeen are not accounted for. Assuming that these 17 are random with respect to the place of birth, 17/2 may be assumed to be immigrants. The adjust figure for immigrants will be $131+8.5=139.5$.

1) I wish to thank Professor William S. LAUGHLIN for his guidance and encouragement in writing this paper. Data were gathered while I worked for Professor Edward NoR$B E C K$ on culture change in northern Japan. 
The percentage of individuals born outside the community will be $28.5 \%$.

II. Size of the breeding population

All the marriages which have contributed gametes to the next generation of the community are grouped in the following six types:
A : $(\mathrm{N} \times \mathrm{N})$ : native married to native
$\mathrm{B}:(\mathrm{N} \times \mathrm{I})$ : native married to immigrants
$\mathrm{C}:(\mathrm{I} \times \mathrm{I})$ : immigrant married to immigrant
$\mathrm{D}:(\mathrm{I} \times$ ? $)$ : immigrant married to a spouse of unknown origin
$\mathrm{E}:(\mathrm{N} \times$ ? $)$ : native married to a spouse of unknown origin
$\mathrm{F}:(? \times ?)$ : both spouses are of unknown origin.

Table I shows the number of cases of each type of marriage, total number of offspring produced by each type of marriage and numbers of parents of each category (native, immigrant or unknown).

Table I

\begin{tabular}{|c|c|c|c|c|c|}
\hline \multirow{2}{*}{$\begin{array}{l}\text { Marriage } \\
\text { type }\end{array}$} & \multirow{2}{*}{$\begin{array}{c}\text { No. of } \\
\text { cases }\end{array}$} & \multirow{2}{*}{$\begin{array}{l}\text { No. of } \\
\text { offspring }\end{array}$} & \multicolumn{3}{|c|}{ No. of parents } \\
\hline & & & Native & Immigrant & Unknown \\
\hline$A: \mathrm{N} \times \mathrm{N}$ & 13 & 40 & $13 \times 2=26$ & & \\
\hline $\mathrm{B}: \mathrm{N} \times \mathrm{I}$ & 60 & 165 & $60-1^{*}=59$ & $60-2^{*}=58$ & \\
\hline $\mathrm{C}: \mathrm{I} \times \mathrm{I}$ & 10 & 28 & & $10 \times 2-1^{*}==19$ & \\
\hline $\mathrm{D}: \mathrm{I} \times ?$ & 12 & 18 & & 12 & $12-1.0 *=2$ \\
\hline $\mathrm{E}: \mathrm{N} \times ?$ & 11 & 25 & 11 & & $11-9^{*}=2$ \\
\hline $\mathrm{F}: ? \times ?$ & 5 & 7 & & & $5 \times 2-4^{*}=6$ \\
\hline Total & 111 & 283 & 96 & 89 & 10 \\
\hline
\end{tabular}

(*: dead parents)

Thus the total number of parents living with their offspring in the community is : $96+89+10=195$.

III. Size of effective breeding population $(N)$

LASKER uses (p. 155) the formula:

$$
N=\frac{4 N^{\prime}-2}{d_{k}^{2}+2}
$$

for the size of effective breeding population. $N^{\prime}$, i. e., the number of parents, was found in the previous section to be 195. BoyD shows the method of obtaining the estimated variance, $d_{k}^{2}$, as follows (p. 374):

$$
d_{k}{ }^{2}=\frac{d^{2} f-\frac{(d f)^{2}}{n}}{n-1}
$$

$d$ is the deviation from the mean and $n$ is the total number of marriages under consideration. In section II $n$ was found to be 111 . Since the total number of 
offspring was 283 , the mean will be

$$
m=\frac{283}{111}=2.5 \text {. }
$$

The number of offspring per marriage varies from 1 to 6 . Frequency of each of these six classes of marriages, deviation from the mean, values for $(d \times f)$ and for $\left(d^{2} \times f\right)$ are shown in Table II.

Table II

\begin{tabular}{|c|c|c|c|c|}
\hline $\begin{array}{c}\text { Marriage size } \\
\text { class }\end{array}$ & $\begin{array}{c}\text { Deviation from } \\
\text { mean }(d)\end{array}$ & $\begin{array}{c}\text { Number of } \\
\text { cases }(f)\end{array}$ & $(d \times f)$ & $\left(d^{2} \times f\right)$ \\
\hline 1 & -1.5 & 39 & -58.5 & 90.00 \\
2 & -.5 & 17 & -8.5 & 4.50 \\
3 & .5 & 24 & 12.0 & 6.25 \\
4 & 1.5 & 19 & 28.5 & 45.00 \\
5 & 2.5 & 10 & 25.0 & 62.50 \\
6 & 3.5 & 2 & 7.0 & 36.75 \\
\hline Total & & 111 & 5.5 & 245.00 \\
\hline
\end{tabular}

Substituting the values obtained above into the formula for $d_{k}^{2}$ given above,

$$
d_{k}{ }^{2}=\frac{245-\frac{(5.5)^{2}}{111}}{111-1}=\frac{244.73}{110}=2.22
$$

The size of effective breeding population will be:

$$
N=\frac{4 \times 195-2}{2.22+2}=184.4
$$

IV. Rate of random gene drift

We use the formula given by LASKER for the rate of random gene drift, assuming the value of $q$ to be .5 .

$$
g=\frac{q(1-q)}{2 N}=\frac{.5(1-.5)}{2 \times 184.4}= \pm 2.6
$$

\section{Rate of admixture}

We follow the method which LASKER sets forth (p. 156) in calculating the rate of admixture, namely, the total number of offspring produced by parents both of whom are immigrants is added to one-half of the offspring produced by parents one of whom is an immigrant, then the sum is divided by the total number of native born individuals.

In calculating the number of natives both of whose parents are immigrants, we must, in addition to the 28 children resulting from the type $\mathrm{C}(\mathrm{I} \times \mathrm{I})$ marriage, take care of the offspring of the marriages of types $D$ and $F$ (see Table I). In type $D(I \times$ ?), where one parent is known to be immigrant, the other is either immigrant or native. Thus we may assume that one-half of the offspring 
resulting from this type of union, viz., 9, to be born of parents who are both immigrants. Type $F($ ? $\times$ ?), may be divided into three possible types of marriage: $(\mathrm{N} \times \mathrm{N}),(\mathrm{N} \times \mathrm{I})$ and $(\mathrm{I} \times \mathrm{I})$. Thus one-third of the offspring of all the unions of type F, viz., 2, may be considered to have been born of immigrant father and mother. In addition, there are 18 native born individuals, not shown in Table I or accounted for previously in this paper, who have not contributed any gametes to the next generation and whose parents are not accounted for, i. e., not known whether native or immigrant. Again, one-third of these, viz., 6, will be assumed to have resulted from $(I \times I)$ type of marriage. The total number of natives both of whose parents are immigrants is, then,

$28+9+2+6=45$.

Next, the total number of natives one of whose parents is immigrant will be calculated in a similar fashion.

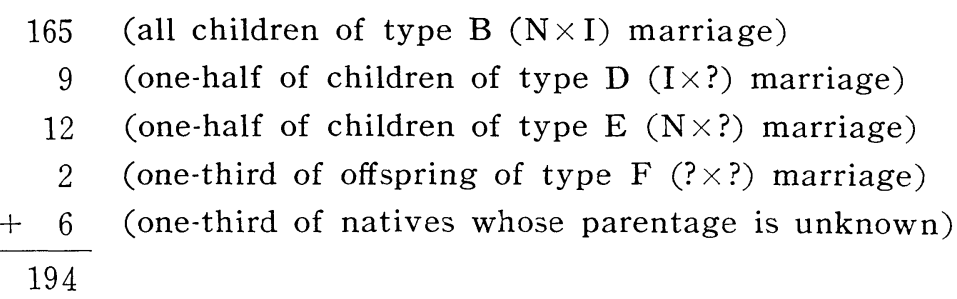

Thus the parental element from outside Shimo-okada community is $-\frac{45+1 / 2 \times 194}{342} \times 100=41.5 \%$.

\section{SUMMARY AND DISCUSSION}

Relevant figures obtained above may be repeated here and compared with those given by LASKER (p. 160). This table is reproduced on the following page (Table III) for comparison with the Shimo-okada data. Most of these figures need no special comment. The size of Shimo-okada is on the smaller side, but there are smaller ones in LASKER's table. The rate of random gene drift is rather typical. Percentage of immigrants is rather high, but not the highest. Effective size of breeding population is again within the range of the extremes found in LASKER's table. However, the proportion of the effective breeding population to the total population is more than one-third, in contrast to LASKER's conclusion that it is about one-fifth for various Middle American communities.

But probably the most striking anomaly in these Japanese data, when compared with LASKER's, is the very high rate of admixture. This is, of course, partly due to the high proportion of immigrants marrying and moving into the community. The highest rate of admixture in LASKER's table is $29.4 \%$ (?) for Tajin. The figure for the Japanese hamlet is more than $10 \%$ above this figure. On a 
cross-cultural basis, this raises some question as to the validity of the contention that the Japanese hamlet is a selfcontained and ingrown unit. On the basis of available evidence, our hamlet must be said to contain highly heterogeneous elements - to a much greater extent, at any rate, than any of the communities studied by LASKER.

Table III Demographic Data and Evolutionary Factors

\begin{tabular}{|c|c|c|c|c|c|}
\hline & $\begin{array}{c}\text { Community } \\
\text { Size }\end{array}$ & \begin{tabular}{|c|} 
Effective \\
Size \\
of Breeding \\
Population
\end{tabular} & \begin{tabular}{|l|} 
Rate of \\
Random \\
Genetic \\
Drift per \\
Generation \\
for a Gene \\
with Frequ- \\
ency of $0.5 \%$
\end{tabular} & $\begin{array}{c}\text { Percentage } \\
\text { of } \\
\text { Individuals } \\
\text { Born } \\
\text { Elsewhere } \\
\%\end{array}$ & $\begin{array}{c}\text { Rate of } \\
\text { Admixture } \\
\%\end{array}$ \\
\hline Paracho, Michoacan (cabecera) & 4593 & 967 & 土1. 1 & 34.9 & 20.2 \\
\hline Quiroga, Michoacan (cabecera) & 3161 & $665 ?$ & 1.4 & 22.6 & $22.6 ?$ \\
\hline Mitla, Oaxaca & 2951 & $621 ?$ & 1.4 & $19.0 ?$ & $3.5 ?$ \\
\hline Tzintzuntzan, Michoacan & 1231 & $259 ?$ & 2.2 & 11.8 & $11.8 ?$ \\
\hline Tajin & 1102 & $232 ?$ & 2.3 & 29.4 & $29.4 ?$ \\
\hline Aguacate & 777 & $163 ?$ & 2.8 & 22.9 & $22.9 ?$ \\
\hline Panajachel, Guatemala & $688-780$ & $145-164 ?$ & $2.8-2.9$ & 16.4 & $5.2 ?$ \\
\hline Ramah, Navaho & $614-634$ & $129-133 ?$ & 3.1 & 4.9 & 5.6 \\
\hline Havasupai & 177 & 39 & 5.7 & - & $7.5-16.2$ \\
\hline Australian aborigines & $100-1500$ & $20.7-316 ?$ & $2.0-7.8$ & 一 & $3.5-10.5$ \\
\hline Ranchos of Quiroga & 133 avg. & $28 ?$ & 6.7 & 10.3 & $10.3 ?$ \\
\hline Camayura, Brazil & 110 & $23 ?$ & 7.4 & $11.8-13.6$ & $11.8-13.6 ?$ \\
\hline Shimo-okada, Japan & 490 & 184.4 & 2.6 & 28.5 & 41.5 \\
\hline
\end{tabular}

As LASKER himself points out, the rate of admixture does not seem to be correlated with the size of community. LASKER also denies that there is "clear correlation between rates of admixture and cultural level." (p. 162) But he admits that apparently in some towns with specialized small industries and highly developed trade and even in agricultural towns, if their structure is less cohesive, a higher admixture rate may prevail.

Japan is a highly industrialized nation. Although our datum community is not specialized in any small industries, it is, of course, part and parcel of a larger, industrialized economic system. Perhaps, then, cultural level of the society of which the community is a part may indeed be, if not directly, indirectly correlated with the rate of admixture. This is suggested as an hypothesis which needs testing-at least from two directions: (1) collection of more data on admixture rate from other communities in Japan, in order to substantiate the figure obtained above, and (2) investigation of communities outside Japan of various cultural level with respect to the rate of admixture. 


\section{REFERENCES CITED}

Boyd, W. C., 1950: Genetics and Races of Man. Boston, Little Brown and Company.

LASKER, C. W., 1960: Human Evolution in Contemporary Communities. In S. M. GARN, ed. Readings on Race. Springfield, Charles C. Thomas, pp. 152-165.

\section{Department of Anthropology \\ Stanford University \\ U.S. A.}

近代山本村淡の檏成䯃素の変化

\section{Harumi BEFU}

仙台市周辺の一農村部落について, 人口構成から, どの程度部落外要素の移入があったかを LASKER （1960）の用いた方法によって算定した。そ机によると，中でも混合率 (Rate of Admixture) が41.5\%と， LASKER の中南米についてしらべた值にくらべ, かなり高い率を示しているのが注目された。てれにつ いては更に日本の他の町村, また日本以外の種々の文化水準の社会の調査を加えて検討する必要がある が，混合率はその社会の文化水準と，直接ではなくとも，関係があると考えられる。 